DOI:

\title{
INTER-ETHNIC COMMUNICATION IN LANGUAGE TEACHING
}

\author{
Liubov Karpets \\ Doctor of Philosophy, Candidate ofPhilology, Associate Professor \\ Kharkiv State Academy of Physical Culture \\ (Kharkiv, Ukraine) \\ email: lubo.karpets@gmail.com \\ Helena Kucherenko \\ Candidate of Philology, Associate Professor \\ Kharkov National University of Civil Engineering and Architecture \\ (Kharkiv, Ukraine) \\ email:kucherenkoef@gmail.com
}

\begin{abstract}
The purpose of scientific research: to analyze the essence of the problem of mastering foreign languages in the process of international communication. The article used the following methods: field research, sociolinguistic analysis of the collected material, problem-situational analysis, active analysis. Within the framework of the survey, respondents determined the level of knowledge of a foreign language, the reason for interest in the culture of other countries, and the intercultural characteristics of learning foreign languages. Among the types of tasks, an analysis of textual, Internet material (video and audio) of an intercultural nature is proposed; systematic discussion of facts highlighting the characteristics of cultures; conducting role-playing games and discussions; writing dialogs with people from different cultures; comparative analysis of proverbs, sayings, phraseological units. Thematic trainings have been conducted that help overcome the difficulties of intercultural communication. To achieve this goal, it is necessary to take into account changes in the world's pictures in the minds of students, which are displayed differently by language means and have different intercultural meaning. The process of transculturation, cultural polylogue should not lead to a complete synthesis, fusion of cultures of the studied languages. Inter-ethnic communication is the interaction and mutual enrichment of cultures.
\end{abstract}

Keywords: inter-ethnic communication, teaching foreign languages, changing the pictures of the world.

\section{МЕЖНАЦИОНАЛЬНАЯ КОММУНИКАЦИЯ В ОБУЧЕНИИ ЯЗЫКАМ}

\author{
Любовь Карпец \\ Доктор философии, кандидат филологии, доцент \\ Харьковская государственная академия физической культуры \\ (Харьков, Украина) \\ email: lubo.karpets@gmail.com \\ Елена Кучеренко \\ кандидатфилологии, доцент \\ Харьковский национальный университет строительства и архитектуры \\ (Харьков, Украина) \\ email:kucherenkoef@gmail.com
}

\begin{abstract}
Аннотация. Цель научного исследования: проанализировать сущность проблемы овладения иностранными языками в процессе межнациональной коммуникации. В статье использованы следующие методы: полевого исследования, социолингвистического анализа собранного материала, проблемно-ситуационого анализа, деятельностный. В пределах проведенного исследования респонденты определяли уровень знаний иностранного языка, причину заинтересованности культурой других стран, межкультурных особенностей изучения иностранных языков. Среди видов заданий предложены анализ текстового, Інтернет материала (видео и аудио) межкультурного характера; системное обсуждениефактов, выделяющих особенности культур; проведение ролевых игр и дискуссий; написание диалогов с представителями разных культур; сравнительный анализ пословиц, поговорок, фразеологизмов. Проведены тематические тренинги, которые помогают преодолеть трудности межкультурной коммуникации. Для решения поставленной цели обязательно необходимо учитывать изменения картин мира в сознании студентов, которые по-разному отображены языковыми средствами и имеют разный межкультурный смысл. Процесс транскультурации, культурный полилог не должен приводить к полному синтезу, слиянию культур изучаемых языков. Межнациональная коммуникация - это взаимодейстие и взаимообогащение культур.
\end{abstract}

Ключевые слова: межнациональная коммуникация, обучение иностранным языкам,изменения картин мира

INTRODUCTION. Language is a universal means of not only receiving and transferring knowledge, information, but also a powerful means of human life and society. This is a socio-cultural mechanism of communication of the past, present, future. Under conditions of globalization, it acquires new features, new drawing. Analysis of the status and strategies of language as a reality of the educational sphere ascertains the new trends in its existence. Speech reality requires careful attitude towards oneself, where the desire to learn, to acquire knowledge, can turn into an educational 
capital of the individual, contributing to its intellectual and spiritual development. Today's rapid development of scientific and technological progress leads to an intensification of the interest in the problem of inter-ethnic communication in education as an important factor in the individual. The basic principles and methods of communication theory were actively developed during the XX century and continue to be developed in the XXI century by scholars from all over the world, since the communicative aspect of language learning, the unresolved intercommunicative problems of linguocultural studies do not lose its relevance in a modern, globalized, inter-ethnic society.

REVIEW OF LITERATURE. The theory of linguistic communication, interethnic communication was the subject of research of scientific works as Ukrainian linguists (F. Baitsevich, A. Ishmuratov, T. Kosmeda, G. Pocheptsov, O. Semenyuk, etc.) and foreign (E. Bern, A. Vezhbitskaya, G. Grais, O. Zalevskaya, V. Karasik, Y. Lotman, O. Matiash, P. Cooper, T. Ushakova, R. Jakobson, etc.).

Due to the definite topic of the study among the terms used, which reveal the essential aspects of the problems of interethnic relations and relations in the educational process at different historical periods of time, the most commonly used are the following: "intercultural communication", "intercultural competence", "intercultural learning methods".

R. Jacobson understood communication as "the process of transferring information between people through sign systems, signals" (Jacobson 1975).

According to Y. M. Lotman, it is extremely important for understanding communication that language knowledge and practical skills to translate the text from the language of your "I" into the language of your "you", the one who transmits information (Lotman 1996).

We share the opinion of F. Batsevych, which distinguishes mechanistic and active communication. Mechanistic communication is a process of transferring information from one participant of a communicative situation to another, and active communication involves the unity of all participants in the communicative process, which results in common views.

O. Matyash is a supporter of psychologization of communication, because the scientist focuses on the interpersonal, interpersonal aspect of human communication (Matyask 2002).

For the proposed research materials are extremely relevant, to our mind, it is necessary firstly to reveal the essence of the term "intercultural communication", which we will use in the future.

In "Glossary of Terms of Intercultural Communication" by F.S. Batsevich the definition of the above term is given: "Intercultural communication - the process of communication (verbal and non-verbal) of people (groups of people) belonging to different national linguocultural communities tends to be used in different idioethnic languages, feel linguocultural "foreignness"of the communication partner, have a different communicative competence that can cause communicative failures or cultural shock in communication "(Bacevich 2007).

The purpose of scientific research is to analyze the problems of effective teaching of foreign languages taking into account the processes of inter-ethnic communication.

RESEARCH METHODS. To achieve this goal, the following methods were used in this research: field research method, sociolinguistic analysis of collected material. The field survey method included questioning and interviewing, as well as direct observation. During the questionnaire respondents were asked to answer the questions that allowed to reveal: the interest in learning a foreign language; the purpose of studying a foreign language; self-esteem in native language; self-assessment of foreign language level; skills that interest most students in learning a foreign language; what language and in what situation one prefers and why; how to assess the aesthetic aspect of a language; how information technology helps in learning languages; the most effective forms of training.

One of the forms of observation was an interview, where questioning and observations were combined. Listening to the informant's answers, the interviewer could simultaneously observe the peculiarities of speaking, 175 people were interviewed.

Among the methods used in the research of this topic, an active method is important, oriented to the sociocultural context of the languages that are functioned and studied. The method is aimed at understanding the language as an active informative and communicative activity of the student as a way to realize the language in society and professional activities.

The application of the method of problem-situation analysis (case study) during language learning contributed significantly to the study of intercultural communication skills.

RESULTS AND DISCUSSION. Within the framework of the survey, respondents answered questions about their knowledge of a foreign language, interest in the culture of other countries, and the peculiarities of studying foreign languages. Among the types of tasks as the implementation of the active method, the following were proposed: analysis of text, Internet material (video and audio) of the intercultural direction; systematic discussion of facts that highlight the peculiarities of cultures of representatives of countries-communicators; conducting role-playing games and discussions, drawing on learned and mastered culturological material; writing imaginary dialogues with representatives of different cultures; comparative analysis of proverbs, sayings, phraseological units.

No less important for the development of intercultural competence are trainings that help to overcome the difficulties of intercultural communication. Through training, you can actually experience specific language learning conditions, apply the peculiarities of intercultural communication in a variety of situations: public speech, conflict resolution and misunderstanding, and constant changes in the cultural environment. Among the actively offered training methods of language teaching, which include the use of educational effects on the effectiveness of the learning process, we should mention brainstorming, role-playing games, group discussions. Group tasks performed during the training 
activities form and develop the intercultural etiquette behavior of the students of one team, contribute to the improvement of their intercultural competence.

The skills of intercultural communication (both language and linguistic) can be improved by applying the following directions of training: "Causes of Efficiency or Inefficiency in Intercultural Communication", "Tolerance as a Significant Factor of Understanding in an Intercultural Environment", "Basic Rules of Ethics of Communication in Interethnic Professional Speech", "Culture of Oral Inter-ethnic Business Communication", "Communicative Interaction in Intercultural Language Communication", "Speech Influence as a Result of Communicative Interaction". "The Role of the Individual in the Process of Preventing and Resolving Conflict Situations", "Features of International Business Etiquette".

Respondents were offered a training on "Features of International Business Etiquette", focusing on its successive structural stages. This training is aimed at active group work out of such tasks: a) definition of features of business etiquette of representatives of different cultures; b) the choice of general behavior, taking into account intercultural differences; c) the selection of the necessary language formulas for each particular communication situation; d) the practical application of selected language means in a group type of task (role play, dialogue or polylogue, discussion). Such trainings aim to teach intercultural communication, developing and enriching the language and speech culture of each of the participants in the communicative process.

The purpose of the study was to identify information regarding the desire to learn foreign languages. As the results of the survey showed, only $15 \%$ of respondents answered negatively. Most showed interest in learning foreign languages (Fig. 1). According to the questionnaire, 90 students study in the first year, representing the majority of the respondents (51\% are boys, $49 \%$ are girls). 50 students - second year and 35 students - fourth year.

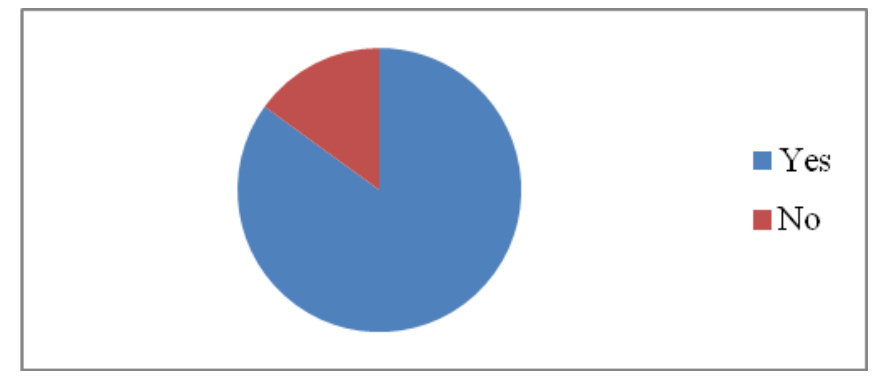

Fig. 1 The desire to learn foreign languages

In order to identify the interest and needs of students, the questionnaire raised the question of determining the purpose of learning a foreign language (Fig. 2). As the survey showed, for the majority of respondents, additional knowledge of a foreign language is required for the professional sphere of activity. Culturological and tourist destination put in the second place. Students understand that the expansion of the horizons enables them to develop, through the language to learn the spiritual world of another country.

The findings of our study demonstrate the average level of knowledge of respondents in foreign languages. The majority of respondents know better English among other foreign languages. This is not a new fact because students mainly study English language.

Most students in the study of foreign languages can see various forms of learning language but most of them are attracted by creative forms, where there is an opportunity to express their views. (Fig. 3).

In this regard, it is important to focus more attention during the classes on the development of oral communication. As you know, "active productive methods that are in line with the logic of a competent approach, there are such forms of team work, as "case-studies" method, simulation-action game, "brainstorming" (Chstelidou, 2011).

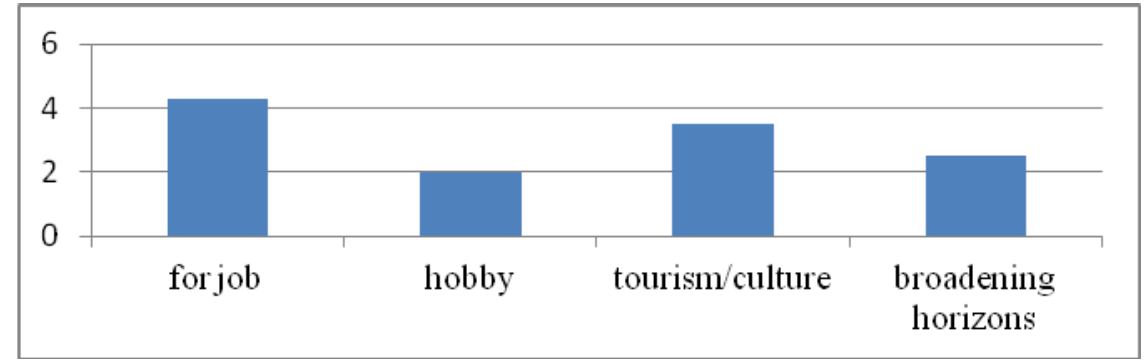

Figure 2. The purpose of studying a foreign language

The purpose of language education can no longer be only the mastering of language knowledge, skills and abilities. The main thing in language education should be the formation of the subject's ability to participate in intercultural communication, which involves the mutual exchange of values and orientations, knowledge and ideological positions that take place in the process of intercultural interaction between subjects.

In the training of national and foreign languages, there is awareness of new, the picture of different cultures and the interaction of these cultures is formed. The intercultural approach determines the relationship between various ethnic 
communities of the community. The result of the dialogue and the polylogue of such relations of communicants should be awareness of national peculiarities, and consequently, sequential and structured actions, which determine the participation of each participant in the intercultural dialogue.

The organization of non-fragmentary knowledge in the modern education system remains ineffective until the language won't become a base of education as a means of knowledge and communication in native and non-native languages. The key in language education is the formation of the ability to participate in intercultural communication. In our opinion, the linguistic space in the conditions of the information society is influenced, on the one hand, by factors of the actual educational space, acting as a general in relation to the linguistic space, and on the other, the specific conditions for the formation of the linguistic space.

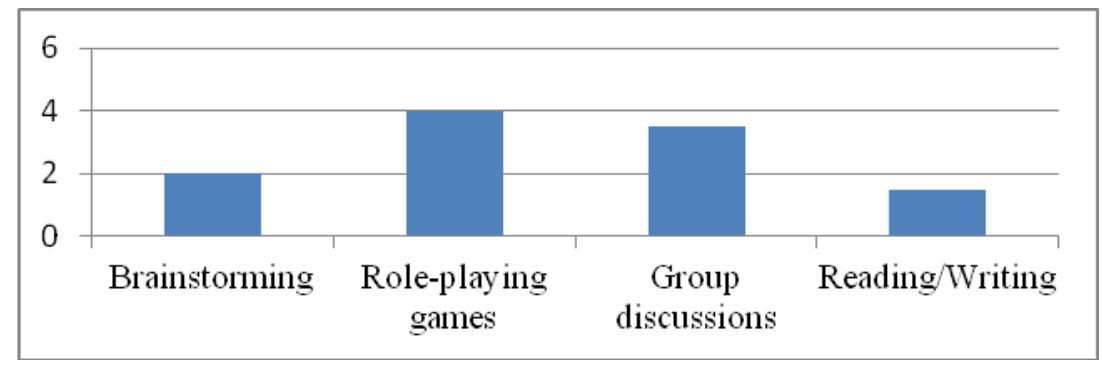

Fig. 3 Forms of classes

CONCLUSION. On the basis of the study, we can state that one of the main problems in mastering a foreign language, for the solution of which requires the appropriate organization of the educational process, is a change in the human consciousness of world paintings, which are differently reflected by linguistic means and carry different ideological load. The level of foreign language skills depends on the level of native language skills that a person learns to think, and the standards of national thinking are naturally transferred to the system of standards of thought, which belong to a foreign language, the so-called process of transculture occurs, there is a cultural polylogue, in which process should not take place complete synthesis, fusion, full cultural translation, where cultures meet, interact, but do not fuse. The process goes beyond the limits of language education. Language education as a process of disclosure and a combination of the worldview is an integrative one, in view of which it is necessary to formulate curricula that allow the adaptation of one world view to the other, to understand that different languages are formed on the basis of certain worldviews. The content of modern education in its essential part does not correspond to the tasks of development of cognitive abilities of the individual. Scientific knowledge, for a more accurate assimilation, was "packaged" in different disciplines and reflects only a certain picture of the world. It is possible to use certain integrated technologies, to create a holistic image of the national culture and to provide the possibility of analyzing the word in the context of the whole culture as a whole, which requires the establishment of interdisciplinary connections and, thus, the integration of the subjects being studied.

\section{LIST OF REFERENCES}

Chstelidou D. Needs-Based Course Design: The Impact of General English Knowledge on the Effectiveness of an ESP Teaching Intervention. Social and Behavioral Sciences. 2011. Vol.15. P.403-409.

LotmanYu. M. (1996) Vnutrimyslyashhixmirov. Chelovek- tekst-semiosfera-istoriya [Inside the thinking words. Man-textsemiosphere-history] [Elektronnyj resurs] / Yu. M. Lotman.- Moskva.Rezhim dostupa: http:wwwphilology.univer.kharkov.ua//katedras/prof_sites/kazakova/leccion_5.pdf.

Matyash O. I.(2002) Chto takoe kommunikaciya i nuzno li kommunicativnoe obrazovanie [What is communication and whether communication education is necessary// Siberia. Philosophy. Education](6), 36.- 47 [Elektronnyj resurs] Rezhim dostupa:http://jarki.ru/upress/2008/10/13/48.

Slovny'kterminivmizhkul'turnoyikomunicaciyi (2007) [Dictionaryoftermsmizkulturnoikomunikaciy] / F.S.Bacevy'ch.

Yakobson R. (1975) Lingvistika i poetica//Strukturalizm «za» i «protiv»[.Linguistics and Poetics// Structuralism: «pros» and «cons»] - Moskva, 193.- 205.

\section{For citation:}

Karpets, L. \& Kucherenko, H. (2019) INTER-ETHNIC COMMUNICATION IN LANGUAGE TEACHING. International Scientific-Pedagogical Organization of Philologists “WEST-EAST” (ISPOP). Scientific Journal WEST-EAST. Vol 1/1 N1 (October, 2019). pp. 152-156. doi:

\section{Для цитирования:}

Карпец, Л., Кучеренко, Е. (2019) МЕЖНАЦИОНАЛЬНАЯ КОММУНИКАЦИЯ В ОБУЧЕНИИ ЯЗЫКАМ // International Scientific-Pedagogical Organization of Philologists “WEST-EAST” (ISPOP). Scientific Journal WEST-EAST. Vol 1/1 N1 (October, 2019). C. 152-156. doi: 
Informationabouttheauthor: Luibov Karpets - Doctor of Philosophy, Candidate of Philology, Associate Professor Kharkiv State Academy of Physical Culture (Kharkiv, Ukraine)

e-mail: lubo.karpets@gmail.com

Сведения об авторе: Любовь Карпец - доктор философии, кандидат филологии, доцент, Харьковская государственная академия физической культуры, (Харьков, Украина)

e-mail: lubo.karpets@gmail.com

Informationabouttheauthor: Helena Kucherenko - Candidate of Philology, Associate Professor, Kharkov National University of Civil Engineering and Architecture, (Kharkov, Ukraine).

email:kucherenkoef@gmail.com

Сведения об авторе: Елена Кучеренко - кандидат филологии, доцент, Харьковский национальный университет строительства и архитектуры, (Харьков, Украина)

email:kucherenkoef@gmail.com

DOI:

\title{
BILINGUAL EXPLANATORY-GRAMMATICAL DICTIONARY AS A MEANS OF TEACHING A FOREIGN LANGUAGE
}

\author{
Tatiana Nikitina \\ Doctor of Philology, Professor \\ Pskov State University \\ (Pskov, Russia) \\ e-mail: cambala2007@yandex.ru
}

\begin{abstract}
The purpose of the project presented in this article is to create a multifunctional dictionary, which will be useful in teaching various types of speech activity and aspects of foreign language. This is achieved through the use of methods of comparative, contextual and linguoculturological analysis in the course of work on the project. The result of the study is the concept of a new type of educational dictionary - bilingual explanatory-grammatical (Russian-Hungarian). The article reveals the differences of this dictionary from traditional lexicographical sources, shows its advantages as a means of teaching a foreign language. The material in the first section of the dictionary is grouped by parts of speech. The second section implements the functional-communicative principle of material arrangement. Thus, the bilingual dictionary, based on the proposed model, provides a comprehensive approach to teaching Russian grammar to foreigners, and can also be useful for Russian-speaking users learning a foreign language.
\end{abstract}

Keywords: educational dictionary, non-native language teaching, Russian language, Hungarian language, adjective

\section{ДВУЯЗЫЧНЫЙ ТОЛКОВО-ГРАММАТИЧЕСКИЙ СЛОВАРЬ КАК СРЕДСТВО ОБУЧЕНИЯ НЕРОДНОМУ ЯЗЫКУ}

\author{
Татьяна Геннадьевна Никитина \\ Доктор филологических наук, профессор \\ Псковский государственный университет \\ (Псков, Россия) \\ e-mail: cambala2007@yandex.ru
}

\begin{abstract}
Аннотация. Цель научно-методического проекта, представляемого в данной статье - создание многофункционального учебного пособия словарного типа, которое будет полезным при обучении различным видам речевой деятельности и аспектам иностранного языка. Это достигается за счет использования в ходе работы над проектом таких методов лингвистического исследования, как сопоставительный, контекстуальный и лингвокультурологический анализ. Результатом исследования стала концепция учебного словаря нового типа - двуязычного толково-грамматического (русско-венгерского). В статье раскрываются отличия данного словаря от традиционных лексикографических источников, его преимущества как средства обучения неродному языку. Материал в первого раздела словаря группируется по частям речи. Здесь системно представлены их морфологические свойства и синтаксическая валентность. Во втором разделе реализуется функциональнокоммуникативный принцип расположения материала: макростатьи объединяют средства выражения пространственных, временных, причинных и других логико-грамматических отношений, изучаемых в курсе русского языка как иностранного (базовый уровень). Таким образом, двуязычный словарь, построенный по предлагаемой модели, обеспечивает комплексный (системно-функциональный) подход в обучении русской грамматике иностранцев, а также может быть полезен русскоязычным пользователям, изучающим иностранный язык.
\end{abstract}

